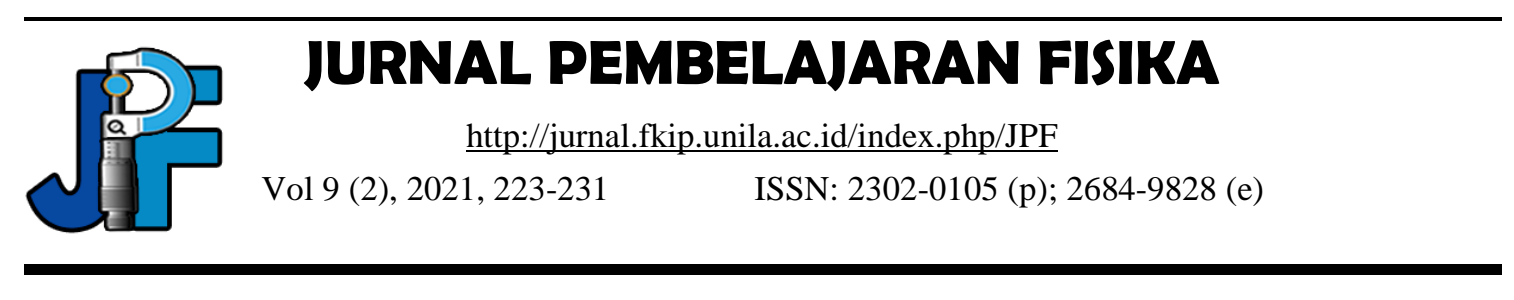

\title{
Implementation of Learning Media Using Augmented Reality Technology for Senior High School Students
}

\author{
Rosynanda Nur Fauziah *, Dwi Sulisworo \\ ${ }^{1}$ Department of Education, Yogyakarta State University, Indonesia \\ ${ }^{2}$ Department of Physics Education, Ahmad Dahlan University, Indonesia \\ *e-mail: Rosynandanur.2021@student.uny.ac.id
}

\begin{abstract}
This study was to determine the use of learning media using augmented reality technology which is applied to senior high school students. The research method used in this research is quasi-experimental with the research design using treatment before and after the use of the learning media. Quasi experimental as an experiment that has treatment, impact measurement, experimental unit, but does not use random assignment to create comparisons in order to conclude changes caused by treatment. The results of the research conducted for the results of the pre-test or before the students received treatment were $69,2 \%$, while the results of the post-test or after the students received treatment were $91 \%$. Then for the average value of the combination of the two tests can be said to be good with the use of learning media using Augmented Reality technology, which is $80,1 \%$. From these results it can be concluded that the application of learning media using Augmented Reality technology provides changes to student learning outcomes in terms of understanding the concept of physics, thus the application of learning media with Augmented Reality technology is successfully applied to high school students for physics subjects.
\end{abstract}

Keywords: augmented reality, learning media, technology

DOI: http://dx.doi.org/10.23960/jpf.v9.n2.202109 


\section{INTRODUCTION}

The 21 st century is marked by the rapid development of information technology and the development of sains in which many routine and repetitive jobs are started by machines, both production machines and computer (Khoiriyah et al., 2019). The development of science and technology can be used positively in the field of education, especially education in this century (Hardiyanto et al., 2012). Education in this century is education that is closely related to technology, especially the application of technology for learning media. The development of technology in the world of education has produced many new innovations to support the learning process (Anggraeni, 2018). One of them is the increasing number of variations of learning media thanks to increasingly rapid technological development (Megahantara, 2017).

The advancement of information media and technology has been felt by the education sector, both in terms of positive and negative aspects of its use. This is because accessing information media and technology is very easy or affordable for various groups, both for teachers, students and parents. Even today the use of information and communication technology is applied in learning media. Learning media is a tool, method, and technique used to assist the learning process in order to streamline, communicate, and interact between teachers and students during the process of learning activities to achieve the desired learning objectives (Suryani, 2010). Technological advances in the field of education affect the creation of the latest learning media (Wiyono \& Zakiyah, 2019). Technology itself provides opportunities for students to learn and apply the 21st century skills needed (Ratheeswari, 2018).

The effective use of technology in education has changed aspects of education and created more educational opportunities (Sumiyati et al., 2019). The application of technology in education is a form of curriculum development based on information and communication technology developed from the education sector (Anwariningsih \& Ernawati, 2013). Technological transformation in the world of education continues to develop and progress until now, it can be seen from the technologies used in education today (Roblek et al., 2016). The influence of information and communication technology in education is that changes can be made by reorienting the curriculum to build competence in the Industrial Revolution 4.0 era and preparing information and communication technology-based learning, for example with hybrid online learning (Bimayu \& Nopriadi, 2019). Therefore by using technology there will be an increase in productivity and quality felt by students (Agrawal et al., 2018).

Education in the era of the industrial revolution 4.0 is a new paradigm in the context of education in which it focuses on innovation and the use of technology, information, communication and the internet (Raja \& Nagasubramani, 2018). One of the important applications in the era of the Industrial Revolution 4.0 is to provide opportunities for students to explore knowledge through technology that suits their needs, one of the sources of technology that can be used by students is Augmented Reality technology (Bacca et al., 2014). Augmented Reality is a technology that combines two-dimensional or three-dimensional virtual objects into reality, and then projects these virtual objects into virtual objects (Budiman, 2016). Augmented Reality is a technology that allows the precise integration of digital content created by computers with the real world (Chen et al., 2019). Augmented Reality or in Indonesian 
translated into Additional Reality is a technique that combines two-dimensional and three-dimensional virtual objects into a three-dimensional real sphere and then projects these virtual objects in real time (Gusmida et al., 2016).

Augmented Reality is a technology that is developing and is in great demand today, because Augmented Reality can fit into various application environments. Augmented Reality can be applied to the fields of knowledge, entertainment, health, and many others. Learning with Augmented Reality technology can be a reference source used by students for learning activities, because virtual objects seem to coexist in the same space as the real world (Bacca et al., 2014). Then learning using Augmented Reality technology will be applied in physics learning in senior high school in class X for the special ray of mirror material which is included in the geometry optics chapter. In addition, to be able to improve understanding of the concept students in learning physics, especially abstract physics concepts, need information technology assistance. Technology (Ismail \& Amalia, 2021).

There have been many studies that examine the use of learning media with Augmented Reality, but each of the research and development certainly has its own characteristics related to Augmented Reality. Both from its use, from the topics raised, who is involved, the stages that are passed during the development process, the obstacles in development. In addition, the focus of the problem studied is related to the implementation of learning media with Augmented Reality in a class carried out by teachers and students. But in this study and the difference with previous research, namely, the implementation of learning media with Augmented Reality technology is implemented for understanding the physics concept of mirror special rays, which are used as auxiliary materials in learning. This special light material is important to be taught using learning media with Augmented Reality technology because at this time we are entering a world with a digital world, which requires everyone to understand and know how the media is used (Fonseca, 2018).

Therefore, this research is different from previous research that has been conducted by Gusmida et al (2016), because in this research, the aim of this research is to development physics learning media using Augmented Reality technology concept of mirror special rays for Class XI SMA without any implementation only until product validation. Therefore, after developing the learning media product, the researcher implemented the learning media in teaching and learning activities. The purpose of this research is to find out the results of the application of learning media using Augmented Reality technology to improve understanding of physics concepts, therefore this research and development must be carried out to determine whether the application of learning media can be accepted by students.

\section{METHOD}

\section{Research Design \& Procedures}

The method used was a quasi-experimental design with one group pretestposttest design (Wibowo et al., 2019). Quasi-experimental research is defined as experimental research, namely research that is used to find certain treatments for others under uncontrolled conditions. The way to overcome this is to compare one or more experimental groups that were given treatment with a comparison group that was not given treatment. 
The design used in this study is a quasi-experimental design and uses a nonequivalent control group design model (Imawati \& Chamidah, 2018). Before being given treatment, both the experimental group and the control group were given a test, namely the pretest, with the intention of knowing the condition of the group before treatment. Then after being given treatment, the experimental group and control group were given a test, namely the posttest, to determine the condition of the group after treatment. The research design can be seen in Table 1.

Table 1. Research Design

\begin{tabular}{ccc}
\hline Pretest & Treatment & Posttest \\
\hline $\mathrm{O}_{1}$ & $\mathrm{X}_{1}$ & $\mathrm{O}_{2}$
\end{tabular}

$\mathrm{O}_{1}=$ Variable before treatment (pre-test)

$\mathrm{O}_{2}=$ Variable after treatment (post-test)

$\mathrm{X}_{1}=$ Treatment (technology Augmented Reality)

Variable $\mathrm{O}_{1}$ is teaching and learning activities before applying learning media with augmented reality technology or before treatment is given and given 5 questions to measure the success rate of using learning media with augmented reality technology. Variable $\mathrm{O}_{2}$ is teaching and learning activities after applying learning media with augmented reality technology or after students are given treatment and given 5 questions to measure the success rate of using learning media with augmented reality technology (Wibowo et al., 2019).

\section{Population and Sample}

The sample of this study consisted of 15 students of class X MIPA 2 at Subang 3 Senior Hight School in the 2020/2021 school year. The population of this study were all students of class X MIPA at Subang 3 Senior High School. This research was conducted in May 2021 in the even semester.

\section{Data Collection and Instrument}

The data collection technique used in this study for the application of learning media with Augmented Reality technology is to used essay questions containing questions related to the material of special ray mirrors. The criteria for implementation learning media with Augmented Reality technology used are based on improvement criteria that can see from the average score after class learning (Imawati \& Chamidah, 2018). Learning media with Augmented Reality technology is to be successfully applied, seen from the increase from the average pretest to post test. The product stimulation criteria for learning outcomes are based on the pretest value of student learning outcomes before learning using learning media with Augmented Reality technology. If the pos test value of student learning outcomes is higher than the pretest value, it can be said that student learning outcomes have increased (Marneanu et al., 2014).

The pre-test questions items related to the application of learning media with Augmented Reality technology consist of 5 questions with essay questions, the maximum score obtained if all are correct is 100 and the maximum score obtained if all 
are incorrect is 0 . In each items the maximum value obtained is 20 points if the answer is correct and correct, the maximum value obtained for each item is 0 if the answer is incorrect and correct. The post-test questions items related to the application of learning media with Augmented Reality technology consist of 5 questions with essay questions, the maximum score obtained if all are correct is 100 and the maximum score obtained if all is incorrect is 0 . obtained is 20 points if the answer is correct and correct, the maximum value obtained for each item is 0 if the answer is incorrect and correct.

\section{RESULT AND DISCUSSION}

Before being given treatment, students are given questions first or it is called a pretest. Figure 1 shows the pre-test results of one of the students in the application of learning media using augmented reality applications, in this case students are given questions about the concept of understanding the physics of special rays of mirrors. Learning media using Augmented Reality technology is used as a tool for learning activities. The results of the students' pretest before being given treatment are as follows, as in figure 1.

Table 2. Pre-test result

\begin{tabular}{|c|c|c|c|c|c|c|c|c|c|c|c|c|c|c|c|}
\hline \multirow[b]{2}{*}{ Question } & \multicolumn{15}{|c|}{ Respondent } \\
\hline & 1 & 2 & 3 & 4 & 5 & 6 & 7 & 8 & 9 & 10 & 11 & 12 & 13 & 14 & 15 \\
\hline 1 & 17 & 12 & 13 & 17 & 8 & 9 & 12 & 11 & 17 & 12 & 18 & 17 & 11 & 16 & 18 \\
\hline 2 & 15 & 14 & 16 & 12 & 17 & 12 & 15 & 16 & 14 & 15 & 12 & 13 & 14 & 13 & 14 \\
\hline 3 & 12 & 16 & 14 & 14 & 15 & 16 & 18 & 12 & 11 & 13 & 15 & 15 & 15 & 15 & 12 \\
\hline 4 & 14 & 17 & 19 & 13 & 15 & 16 & 12 & 15 & 15 & 15 & 9 & 8 & 11 & 13 & 19 \\
\hline 5 & 18 & 16 & 11 & 12 & 10 & 13 & 14 & 12 & 14 & 12 & 16 & 10 & 14 & 12 & 10 \\
\hline Amount & 76 & 75 & 73 & 68 & 65 & 66 & 71 & 66 & 71 & 67 & 70 & 63 & 65 & 69 & 73 \\
\hline Average & & & & & & & & 9,29 & & & & & & & \\
\hline
\end{tabular}

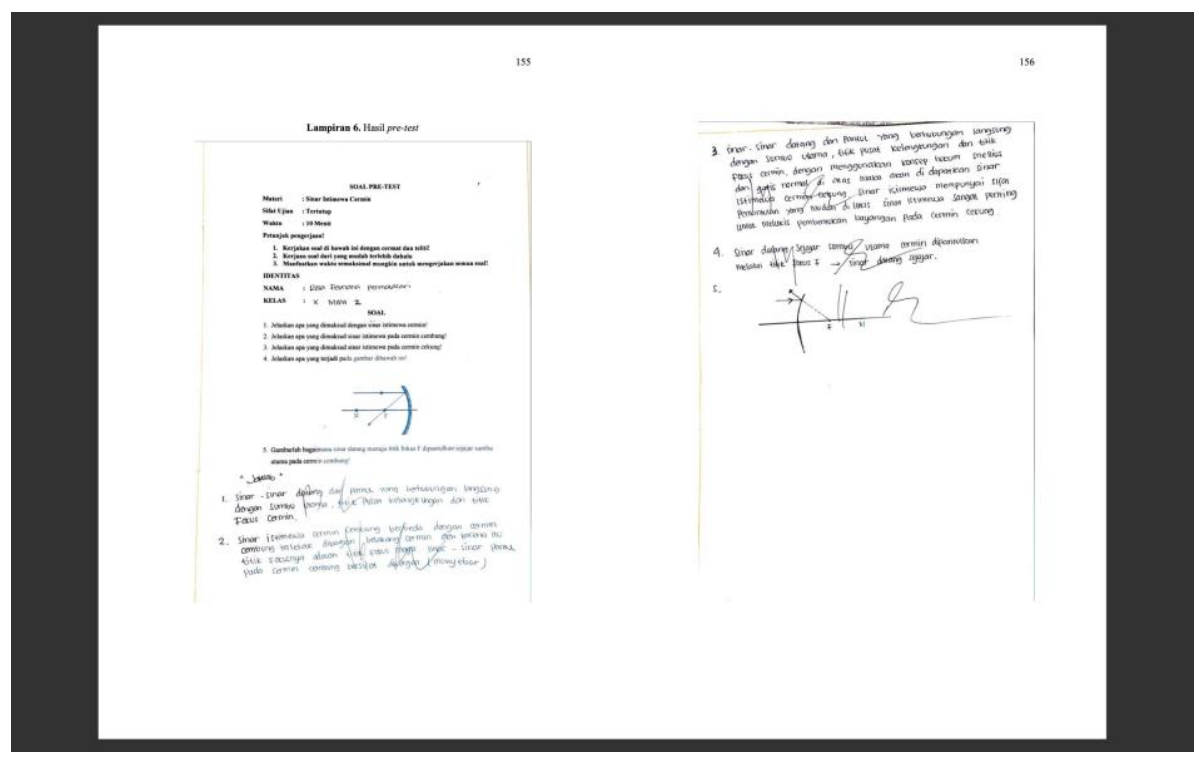

Figure 1. Student's pretest answer based 
Table 1 shows the results of calculating the average value of 15 students who worked on the pretest before being given treatment using learning media with Augmented reality technology (Kusumandari et al., 2018). By adding up the overall scores of each respondent, the average pre-test score of 15 respondents was $69.2 \%$, so it can be said that students' understanding of the special light mirror material is included in the sufficient category. So it takes the application of a media that can improve students' understanding of physics concepts.

After being given treatment using augmented reality technology-assisted learning media, the respondent was re-assessed in the form of a post-test. It aims to find out the results of the application of augmented reality-assisted learning media on understanding the physics concept of mirror special rays. in Figure 2 there are 5 posttest questions to assess the application of Augmented Reality applications as learning media used.

Table 3. Post-test result

\begin{tabular}{|c|c|c|c|c|c|c|c|c|c|c|c|c|c|c|c|}
\hline \multirow[b]{2}{*}{ Question } & \multicolumn{15}{|c|}{ Respondent } \\
\hline & 1 & 2 & 3 & 4 & 5 & 6 & 7 & 8 & 9 & 10 & 11 & 12 & 13 & 14 & 15 \\
\hline 1 & 18 & 17 & 19 & 19 & 17 & 19 & 18 & 17 & 19 & 19 & 17 & 17 & 16 & 18 & 16 \\
\hline 2 & 19 & 16 & 19 & 18 & 18 & 18 & 19 & 16 & 19 & 20 & 16 & 17 & 17 & 18 & 17 \\
\hline 3 & 20 & 18 & 18 & 20 & 17 & 19 & 19 & 19 & 18 & 20 & 20 & 19 & 18 & 17 & 19 \\
\hline 4 & 17 & 20 & 16 & 20 & 17 & 19 & 18 & 19 & 19 & 18 & 20 & 20 & 19 & 17 & 16 \\
\hline 5 & 18 & 20 & 15 & 19 & 16 & 18 & 20 & 19 & 19 & 17 & 18 & 20 & 18 & 19 & 20 \\
\hline Amount & 92 & 91 & 87 & 96 & 85 & 93 & 94 & 90 & 94 & 94 & 91 & 93 & 88 & 89 & 88 \\
\hline Average & & & & & & & & $91 \%$ & & & & & & & \\
\hline
\end{tabular}

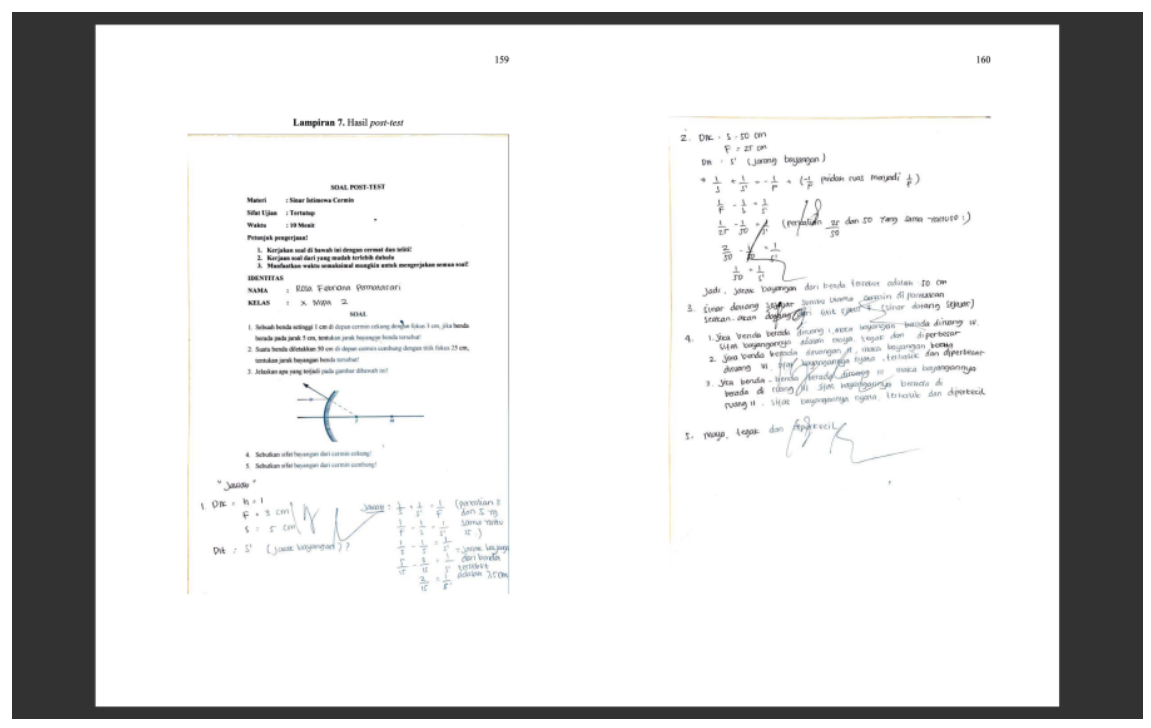

Figure 2. Student's posttest answer based 
Table 4. Result of using implementation augmented reality technology

\begin{tabular}{cccc}
\hline No & Test & Score \\
\hline $\mathbf{1}$ & Pre-test & $69,20 \%$ \\
\hline $\mathbf{2}$ & Pos-test & & $91 \%$ \\
\hline Average & & $80,1 \%$ & \\
\hline
\end{tabular}

From the results of the post-test that has been carried out on 15 respondents, the average value of $91 \%$ is obtained in the very good category. After being given treatment, the post-test scores obtained by the respondents also experienced a significant increase compared to the pre-test scores before being given treatment.

After learning by implementing learning media with Augmented Reality technology on the understanding of physics concepts has a major influence on the results obtained. Based on the calculation results, the average pre-test score of students is $69.2 \%$ of the maximum value of $100 \%$ and the average post-test score of $91 \%$ of the maximum value of $100 \%$, and the combined value of the two exercises is $80.1 \%$ and in the implementation category Augmented Reality Technology has been successfully applied in learning. The learning process using learning media with Augmented Reality technology is easy to use compared to the conventional learning process (Pebrianti, 2014).

This research was conducted to determine the results of the implementation of learning media with Augmented Reality technology on understanding the concept of physics in the material of special rays of mirrors, and this research has differences with Sumardani et al., (2019). The study did not include conceptual understanding to determine learning before and after the treatment, previous research only reached the stage of development learning media with Augmented Reality technology.

\section{CONCLUSION}

It can be concluded that the use and utilization of learning media using Augmented Reality technology has been successfully carried out, judging from the results before and after the treatment faced by students in the process of learning activities. learning activities using learning media with Augmented Reality technology can improve student learning outcomes, it can be concluded from the results of students' scores before being given treatment in a position below the good category, while students' scores after being given treatment are in good categories with very satisfying results.

\section{REFERENCES}

Agrawal, A., Schaefer, S., \& Funke, T. (2018). Incorporating Industry 4.0 in Corporate Strategy. Analyzing the Impacts of Industry 4.0 in Modern Business Environments, 161-176. https://doi.org/10.4018/978-1-5225-3468-6.ch009

Anggraeni, C. W. (2018). Promoting Education 4.0 in English for Survival Class: What are the Challenges? Metathesis: Journal of English Language, Literature, and Teaching, 2(1), 12. https://doi.org/10.31002/metathesis.v2i1.676 
Anwariningsih, S. H., \& Ernawati, S. (2013). Development of Interactive Media for ICT Learning at Elementary School Based on Student Self Learning. Journal of Education and Learning (EduLearn), $7(2), \quad 121$. https://doi.org/10.11591/edulearn.v7i2.226

Bacca, J., Baldiris, S., Fabregat, R., Graf, S., \& Kinshuk. (2014). International Forum of Educational Technology \& Society Augmented Reality Trends in Education : A Systematic Review of Research and Applications. Educational Technology, 17(4), 133-149.

Bimayu, W., \& Nopriadi, N. (2019). Learning Based on Information Technology and Learning Strategy Communication in Facing Industrial Revolution Era 4.0. International Journal of Educational Review, 1(2), 77-86. https://doi.org/10.33369/ijer.v1i2.8849

Budiman, R. D. A. (2016). Developing Learning Media Based on Augmented Reality (Ar) To Improve Learning Motivation. JETL (Journal Of Education, Teaching and Learning), 1(2), 89. https://doi.org/10.26737/jetl.v1i2.45

Chen, Y., Wang, Q., Chen, H., Song, X., Tang, H., \& Tian, M. (2019). An overview of augmented reality technology. Journal of Physics: Conference Series, 1237(2). https://doi.org/10.1088/1742-6596/1237/2/022082

Fonseca, L. M. (2018). Industry 4.0 and the digital society: concepts, dimensions and envisioned benefits. Proceedings of the International Conference on Business Excellence, 12(1), 386-397. https://doi.org/10.2478/picbe-2018-0034

Gusmida, R., Rahmad, M., \& Islami, N. (2016). Pengembangan Media Pembelajaran Fisika Menggunakan Teknologi Augmented Reality pada Materi Teori Kinetik Gas SMA Kelas XI. Jurnal Online Mahasiswa Fakultas Keguruan Dan Ilmu Pendidikan Universitas Riau, 3, 1-12.

Hardiyanto, W., Kurniawan, E. S., \& Nurhidayati. (2012). Pemanfaatan Media Pembelajaran Fisika Berbasis Macromedia Flash 8 Guna Meningkatkakan Motivasi Belajar Siswa Pada Pokok Bahasan Sifat Mekanik Bahan Kelas X Tkj 2 SMK Batik Perbaik. Pemanfaatan Media Pembelajaran Fisika Berbasis Macromedia Flash 8 Guna Meningkatkakan Motivasi Belajar Siswa Pada Pokok Bahasan Sifat Mekanik Bahan Kelas X Tkj 2 SMK Batik Perbaik, Radiasi, $V(1), 1-4$.

Imawati, Y., \& Chamidah, A. N. (2018). Efektivitas media berbasis augmented reality terhadap kemampuan anak tunarungu mengenal kebudayaan Yogyakarta. $J P K$ (Jurnal Pendidikan $\quad$ Khusus), 26-34. https://doi.org/10.21831/jpk.v14i1.25164

Ismail, A., \& Amalia, I. F. (2021). Penerapan Model Pembelajaran Problem Solving Berbantuan Augmented Reality Untuk Meningkatkan Pemahaman Konsep Mahasiswa Pada Mata Kuliah Fisika Umum. Jurnal PETIK, 7(2), 87-92.

Khoiriyah, N., Abdurrahman, \& Suyatna, A. (2019). Development of Comics Physics Education with STEM for Stimulating Straight Line Motion Concept Mastery in Junior High School Students. Jurnal Pembelajaran Fisika, 7(2), 77-85. 
Kusumandari, D. E., Sesunan, F., \& Wahyudi, I. (2018). Implementasi Model Pembelajaran Inkuiri Menggunakanstrategi React Untuk. 1(November), 437446.

Marneanu, I., Ebner, M., \& Rößler, T. (2014). Evaluation of augmented reality frameworks for android development. International Journal of Interactive Mobile Technologies, 8(4), 37-44. https://doi.org/10.3991/ijim.v8i4.3974

Megahantara, G. S. (2017). Pengaruh Teknologi Terhadap Pendidikan Abad 21. Jurnal Pendidikan, 4(2), 1-7.

Pebrianti, D. (2014). Efektifitas Model Pembelajaran Perubahan Konseptual Untuk Mengatasi Miskonsepsi Fisika Pada Siswa Kelas X Sman 1 Praya Barat Tahun Pelajaran 2012/2013. Lensa: Jurnal Kependidikan Fisika, 2(1), 150. https://doi.org/10.33394/j-lkf.v2i1.296

Raja, R., \& Nagasubramani, P. C. (2018). Impact of modern technology in education. Journal of Applied and Advanced Research, 3, S33-S35. https://doi.org/10.21839/jaar.2018.v3is1.165

Ratheeswari, K. (2018). Information Communication Technology in Education. Journal of Applied and Advanced Research, 3, S45-S47. https://doi.org/10.21839/jaar.2018.v3is1.169

Roblek, V., Meško, M., \& Krapež, A. (2016). A Complex View of Industry 4.0. SAGE Open, 6(2). https://doi.org/10.1177/2158244016653987

Sumardani, D., Wulandari, A., Ramdina S, A. N., \& Doriza, S. (2019). Penerapan Teknologi Augmented Reality Pada Media Pembelajaran Poster Tatasurya. Prosiding Seminar Nasional Fisika (E-Journal), VIII, 451-456. https://doi.org/10.21009/03.SNF2019.01.PE.57

Sumiyati, N., Rosidin, U., \& Suyatna, A. (2019). The Implementation of Performance Assessment Instruments to Enhance Students' Collaboration and Communication Skills. Jurnal Pembelajaran Fisika, 7(1), 29-36. https://doi.org/10.23960/jpf.v7.n1.201904

Suryani, A. (2010). Ict in Education: Its Benefits, Difficulties, and Organizational Development Issues. Jurnal Sosial Humaniora, 3(1), 106-123. https://doi.org/10.12962/j24433527.v3i1.651

Wibowo, S., Suyanto, E., \& Nyeneng, I. D. P. (2019). The Effect of Problem Based Learning to Improve Students' Creative Thinking. Jurnal Pembelajaran Fisika, $7(2), 77-85$.

Wiyono, K., \& Zakiyah, S. (2019). Pendidikan Fisika Pada Era Revolusi Industri 4 . 0 Di Indonesia. Seminar Nasional Pendidikan Program Studi Pendidikan Fisika, l(1), 1-14. http://snpfmotogpe.ulm.ac.id/wp-content/uploads/2019/03/ArtikelKetang-Wiyono.pdf 